\title{
VALUE STREAM MAPPING AND ITS SIGNIFICANCE IN THE PRODUCTION PROCESS
}

\author{
Daniela Onofrejova \\ Technical University of Kosice, Faculty of Mechanical Engineering, Department of \\ Industrial Engineering and Management, B.Nemcovej 32, 04200 Kosice, Slovakia, e-mail: daniela.onofrejova @ tuke.sk \\ Jaroslava Janekova \\ Technical University of Kosice, Faculty of Mechanical Engineering, Department of \\ Industrial Engineering and Management, B.Nemcovej 32, 04200 Kosice, Slovakia, e-mail: jaroslava.janekova@ tuke.sk \\ Keywords: value stream mapping, value added, value flow \\ Abstract: Monitoring of flows (material, information, personal, energy, financial, etc.) in the production process is \\ always inevitable approach while searching for improvements. There are, radical improvements known as innovations, \\ and continuous improvement established by KAIZEN principles and its useful methods. Both approaches focus on \\ processes that add value, and minimise or eliminate those without added value. The main target of this paper is to \\ analyse the Value stream mapping approach and its benefit to the practical world.
}

\section{Process Improvement}

\subsection{Methods for Improvement}

The border between process innovation and improvement of processes has been clearly established. Innovation creates in the process higher radical change leap. Improvement can be understood as continuous daily activities of people involved in a process that aims to increase the efficiency of the process itself (reducing wastes, costs, downtime, increasing performance and quality). Elementary differences between innovation and improvement of processes can be found in Table 1. When improving the entire process chain as a comprehensive system of processes it is Value Stream Mapping.

\subsection{Value Stream Mapping}

Being capable to apply the principles of Lean techniques and due to method VSM (Value Stream Mapping) find and configure a bottleneck, so that raised the level of effective production and associated revenuegenerating, it is necessary to collect the data. Having a data offers the opportunity to understand the observed phenomenon. Therefore, define what the value stream mapping method is focused on, detail value streams what essentially it entails and comprise of values.

Value stream, flow values or entities is a comprehensive package of activities that are in the process of transformation of materials into products, and thus causes the final value for the customer. However, it includes activities that add and not add value to the final product. Flow values can also refer to the total events around the product in real time, which provides transformation of a product from idea to introduction on the market.
Table 1 Elementary differences between innovation and improvement of processes

\begin{tabular}{|l|c|c|}
\hline Field & Improvement & Innovation \\
\hline Benefits & $\begin{array}{c}\text { Thousands - ten } \\
\text { thousands euro }\end{array}$ & $\begin{array}{c}\text { Hundreds } \\
\text { thousand euro and } \\
\text { more }\end{array}$ \\
\hline $\begin{array}{l}\text { Employees } \\
\text { involvement }\end{array}$ & $\begin{array}{c}\text { individual, } \\
\text { workshop, cascade } \\
\text { workshop, SixSigma } \\
\text { projects }\end{array}$ & innovation project \\
\hline Impact area & local issue & $\begin{array}{c}\text { limited - } \\
\text { specialists }\end{array}$ \\
\hline Time & short (days, weeks) & long (months) \\
\hline Methods & $\begin{array}{c}\text { intuitive } \\
\text { (brainstorming, } \\
\text { workshop) }\end{array}$ & $\begin{array}{c}\text { systematic } \\
\text { (WOIS, TRIZ) }\end{array}$ \\
\hline $\begin{array}{l}\text { Results } \\
\text { measurement }\end{array}$ & $\begin{array}{c}\text { Team productivity, } \\
\text { savings, cost } \\
\text { reduction }\end{array}$ & $\begin{array}{c}\text { Team creativity, } \\
\text { new value, } \\
\text { originality, } \\
\text { difference }\end{array}$ \\
\hline Environment & $\begin{array}{c}\text { improved process, } \\
\text { use of local } \\
\text { knowledge }\end{array}$ & $\begin{array}{c}\text { Detachment from } \\
\text { current stave, use } \\
\text { of global } \\
\text { knowledge }\end{array}$ \\
\hline
\end{tabular}

The product, during its life cycle, follows the journey two main streams [1]:

- The flow of design from the "drawing table" to the start of production

- production flow from raw materials to delivering the product to customers.

When using the method of VSM, generally in most cases the primary material (transition) flow is being monitored, which has the majority part regarding the 


\section{VALUE STREAM MAPPING AND ITS SIGNIFICANCE IN THE PRODUCTION PROCESS}

Daniela Onofrejova; Jaroslava Janekova

transformation of the material into the final product. Equal importance due to mapping posses the flows that accompany the material flow and are of necessary support, respectively which finally form the flow information, personnel, waste, energy and others.

Material flow according to source [2] can be defined as that the material flow is defined as an organized movement of material (raw material, work in progress, finished goods, scrap) in the production or circulation, expressed by:

- frequency - number of shipments per unit time (valid for discrete ways of handling)

- intensity - the amount transported per unit of time,

- length - the distance that the material must pass from the source to the end points,

- power - the product of the intensity and length of material flow,

- direction - the difinition of placement from - to,

- handling factor - number of realized handling operations.

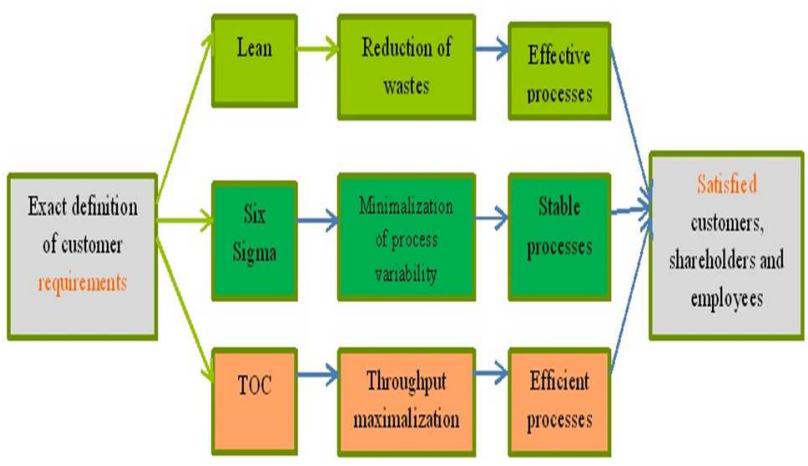

Figure 1 Common principles of Lean, Six Sigma and TOC

Material flow is influenced by several factors:

- volume and the range, nature and type of production,

- level of technological complexity and segmentation processes and assemblies, groups,

- number of operations of individual parts and workplaces,

- shape, segmentation of the space,

- operational method, and the inter-departmental transport,

- location of auxiliary and ancillary operations and services (expenditure tools, maintenance office),

- location of cooperating and outsourcing production departments, sections, units, etc.

Straightforward and simple course is dependent on optimal spatial distribution of the company (production and storage buildings) as well as series of separate operations and appropriate organization of production [2].

The principles of effective organization of material flows and creation of productive disposition are, as follows: [3]
- minimization of performances, minimizing shipping costs - handling and transport operations do not add product value.

- minimizing space - depending on the location of workplaces, balancing capacity,

- provision of safety and hygiene requirements,

- flexibility and freedom of future changes,

- suitability for teamwork,

- minimizing inventory and intermediate times,

-simple material flow - clear, without unnecessary crossings.

- connection to external logistics chain.

In recent years, many enterprises implement effective management concepts. The closest connection with the one of those concepts for the Lean Enterprise are (Figure 1):

- Six Sigma

- Lean

- Theory of Constraints (TOC).

Lean, Six Sigma and TOC are looking at the business through the eyes of the customer and try at minimum cost to meet customers' requirements. TOC focuses on the systematic search of bottlenecks in the enterprise, maximizing flow, minimize inventory and operating costs. TOC provides a very effective tool for managing bottlenecks in production, distribution and project - DBR (Drum Buffer Rope theory) and Critical Chain. DBR can be considered as an alternative to Kanban system with a focus on bottlenecks.

Six Sigma seeks to systematically reduce process variability and increasing their utilization. This is not about the dispersion due to the quality, but the stabilization time, and other parameters necessary for the synchronization of processes in the Lean Enterprise. Six Sigma and TOC provides a sophisticated system for managing changes.

Value Stream Mapping (VSM) is a useful tool for the transfer of an ordinary enterprise to a Lean Enterprise. Broadly, there are two ways to generate (higher) earnings (Figure 2), their principles are as follows:

I. The conventional way - enterprise needs more revenue, thus increases sales price, without trying to reduce costs. A reaction to the price increase, however, is usually a drop in sales.

II. Slim operates - to increase the difference between the cost and the revenues could help enterprise to reduce costs, elimination of waste, extending the bottleneck, respectively its effective use.

Lean thinking is aimed at removing all activities that do not add customer value (defined by the customer). When applied to Lean Manufacturing practices, companies have to adhere to some basic principles of Lean Manufacturing [4], [7], [10].

Value flow, and the flow of entities, comprises of all the processes (increasing or not increasing the values), which is on the way from the material to the finished product. Flow entity management is an essential tool for 


\section{VALUE STREAM MAPPING AND ITS SIGNIFICANCE IN THE PRODUCTION PROCESS}

Daniela Onofrejova; Jaroslava Janekova

the analysis of waste in processes in manufacturing, logistics, development and administration. It allows planning the changes in the flow of the objectives for modeling the current and future values and state. It is therefore a tool for analyzing processes and improving their communication [5], [8], [11].

The significance of value flow management embodies:

- Graphical representation of the current value stream - value stream map,

- Define new, efficient flow of entities to the customer and its continuous improvement,

- Making steps that change process from the current to the new state.

The potential scale and complexity of mapping allows various applications: the production with high repeatability and uniformity, the mapping of processes in production, during operations, processes between enterprises and logistics during the administrative and development processes. However, it is inappropriate for custom production, where cycle times are too long.

Benefits according to [6], [9] achieved by application of the method: Reduction of production lead times of 20 to $50 \%$ in a few days, reduction in the area (operation space), better understanding of the process course and the links between them - the "big picture", simplifying management system, reduction batches and process synchronization, elimination of waste from the process.

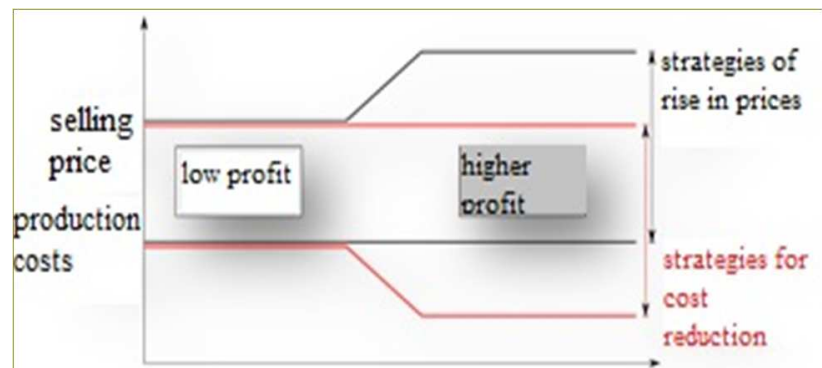

Figure 2 Principles for generating higher earnings

\subsubsection{VAI - value added index}

Index value added output as Value Stream Mapping is the proportion of times that add and not add value to products produced in the analyzed company. Index is visual and numerical confirmation of assumptions where is the bottleneck of the company. When looking for bottlenecks and VSM operations, time (time traces of cycle times) represent key information. The necessary time values are not acquired from the official figures, reported as performance parameters of the machine, but from the actual measurement times measured in production. Particularly at the production plant, which is semi-automated - part of the work is performed by workers and one part by the machinery. A large part of production is carried out in the analyzed company mutually as a man - machine interfaction. Measured times are listed and written in pencil on a paper.

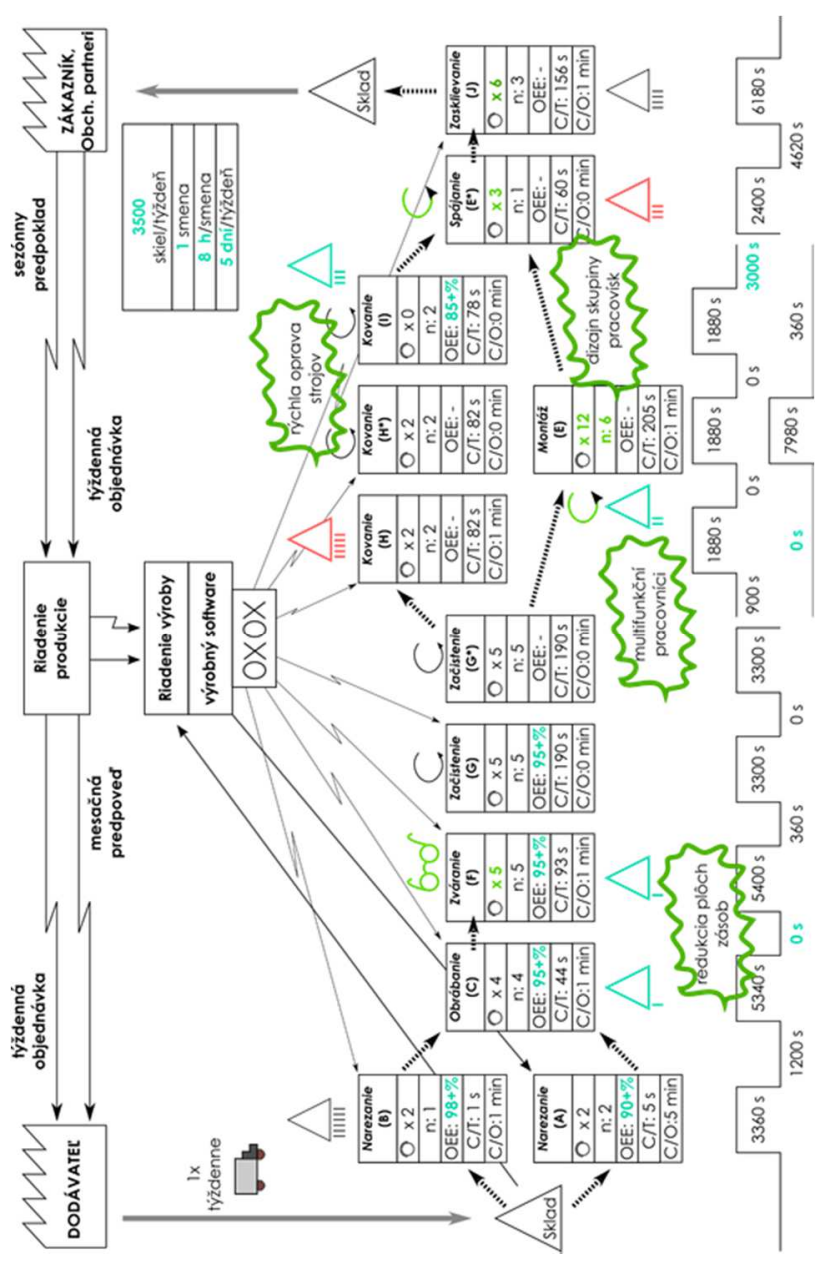

Figure 3 Future state of the production improvements using VSM method

Obtaining time data on production flows and knowledge about the production plant, next step is to create value stream maps. Base maps are manufacturing processes that convert the sequence of input material obtained from suppliers on the finished product shipped to customers through business partners. To create a map of the current state of enterprise value streams one need to get a picture of the manufacturing enterprise. The value streams map contains following information:

- customer orders,

- working hours,

- ordering of materials from suppliers,

- inventory and stockpiling before the trial processes

- workplace, production processes and technological operations,

- material processing times,

- downtime times for material.

Using these data and knowledge, it is possible to create a value stream map (VSM). Such maps gives a comprehensive view of the operation of the company, focusing on manufacturing operations. The output of maps are graphically outlined VAI timelines of monitored 
VALUE STREAM MAPPING AND ITS SIGNIFICANCE IN THE PRODUCTION PROCESS

Daniela Onofrejova; Jaroslava Janekova

production batches, necessary for calculation of material processing times that adds value to the product, hence the customer and production company and times that do not add value to the product. The ratio in these times set VAI (Value Added Index).

$$
\text { Value Added Index }=\frac{\sum_{t} t_{A V}}{t_{N A V}}
$$

where

$t_{A V}$ - sum of times that add value,

$t_{N A V}-$ sum of times that do not add value.

\section{Conclusions}

Acquiring times at a workplace individually can enable to monitor parameters from manufacturing processes, but to obtain a comprehensive overview of production flows and in efforts to the Value Streams Mapping, one must obtain information on the flow material, information, personnel directly at the production plant. Using the method VSM - Value Stream Mapping as a tool to redesign the manufacturing flow is, a key output is VAI - Added Value Index. This value compares the times that do not add value and times that add value in a process of products manufacture. In this case, technological operations, which transforms an input to the finished product are activities that add value. Production flow in the production plant (Figure 3) is not smooth, there are frequent material downtimes (or work in progress) due to inventory accumulation next to technological operations - it is an activity that does not add value to the product and therefore neither the customer nor manufacturing company.

In terms of theories of continuous improvement (Kaizen), Lean Production and cost reduction (Lean Logistic) and bottlenecks, the target is to to uncover bottlenecks, expand bottlenecks and minimize stockpiling in front of such operation unit. Helpful here, there are the time frames of different production batches obtained from the normal operation of the production facility in the analyzed company. These time frames also represent the process of mapping the value stream operation continuity of the production flow, material flow operation, obtaining information and creating information flow.

\section{Acknowledgement}

The research leading to these results has received funding from the scientific project VEGA 1/0879/13 Agile, adapting to market business systems with highly flexible corporate structure and the project KEGA 079 TUKE4/2013 Innovation in laboratory technology educational program of study Industrial Engineering.

\section{References}

[1] ROTHER, M., SHOOK, J.: Learning to see. Lean enterprise institute, Brooklin 1999.

[2] BIGOŠ, P., KISS, I., RITÓK, J.: Material Flow and Logistics logistika. Michala Vaska, Kosice, 2002 (Original in Slovak).

[3] KOSTURIAK, J. et al.: Design of Production Systems for 21. Century. Zilina, ESIS, 2000. (Original in Slovak)

[4] SKOLAR, P.: VSM - Value Stream Mapping, [online], Available: www: http://www.utb.cz/file/24118_1_1/ [23 Febr 2015], 2015. (Original in Czech)

[5] KOSTURIAK, J., FROLIK, Z.: Lean and Innovative Enterprise, Alfa, 2006, 237 pp.. (Original in Czech).

[6] KOSTURIAK, J., BOLEDOVIC, L., KRISTAK, J., MAREK, M.: Kaizen - Prooved Studies in Czech and Slovak Enterprises, Computer Press Brno, 2010, 234 pp., (Original in Czech).

[7] KOROBANICOVA, I., PACUTOVA, G.: 'The human capital in the creative economy in region ', In: CERS 2014, Kosice: TU, pp. 421-431, 2015.

[8] ONOFREJOVA, D.: Process Innovation Models in Service Providing Companies, Innovation transfer, No. 29, pp. 259-263, 2014.

[9] SZABO, S., FERENCZ, V., PUCIHAR, A.: Trust, Innovation and Prosperity. In: Quality Innovation Prosperity, Kvalita Inovácia Prosperita, Vol. XVII, No. 2, pp. 1-8, 2013.

[10] BOŽEK, P., MORAVČÍK, O., ŠTOLLMANN, V., ŠURIANSKY, J., PRAJOVÁ, V., WALEKOVÁ, G.: Virtual program imported into the real technological workplace. In: Annals of DAAAM and Proceedings of DAAAM Symposium. p. 0157-0158, 2008.

[11] ONOFREJOVA, D.: Patterns for production improvement by technology innovation in manufacturing company, Innovation transfer. No. 29, pp. 290-293, 2014.

\section{Review process}

Single-blind peer reviewed process by two reviewers. 